\title{
Revenge, Representation and the Importance of Memory in Susana Torres Molina's Una noche cualquiera
}

\section{Amalia Gladhart}

Susana Torres Molina's Una noche cualquiera (1999) revisits many of the elements of her earlier plays, among them role-playing, self-conscious theatricality and cross-dressing. In Una noche cualquiera, however, the violence between characters is greater, if less defined, and its motivation is explained only near the end. Like other contemporary Argentine plays, such as Griselda Gambaro's Atando cabos (1991), Una noche cualquiera addresses the aftermath of the so-called "dirty war" and the seemingly casual encounters that inevitably occur in a society in which victims and victimizers must coexist. The guilty on trial here are not the actual assassins but their accomplices: collaborators, infiltrators, those who profited or simply managed to find themselves always on the winning side. At stake in the play is the possibility of such coexistence, the nature of the encounters between the victimized and the complicit, and the possibility of vengeance and visibility, of showing on stage not only the crimes committed but an adequate response to those crimes. The sense that both pain and retribution have been meted out arbitrarily is also underscored. As the play's title suggests, the encounter among the six characters on stage could happen at any time. The play's final scene raises, but does not resolve, the question of whether, in fact, closure, or justice, is even possible.

All of the play's action takes place under the watchful eye of four video cameras, two aimed at the performers, two at the audience. The stage also holds four monitors that transmit the images recorded by the cameras. Two further monitors are connected to broadcast channels and transmit their silent images for the duration of the play. The use of the video cameras and monitors complicates the role of the audience and raises issues of repetition, 
memory and documentation. The physical clutter of silver objects that fill a table on stage is echoed by the visual clutter produced by the accumulation of images. The presence of television on stage also calls into question, however indirectly, the relationship of theatre to electronic or video media. The interplay of video and live performance in the representation of confrontation and retribution raises questions about the nature of evidence or testimony, about the space of confrontation, and about the possibilities of theatre. Memory becomes important as evidence and as a call to justice.

The attempt to understand a relatively recent past is not necessarily more straightforward than "uncovering" a past long dead. Elizabeth Jelin argues:

When analyzing memory, we are dealing with multiple intersubjectivities, multiple transmissions and receptions of memories that are fragmented and contradictory, made up of pieces, shreds and patches of one layer on top of another, of traces, monuments and amnesias. When historical memory is seen in a collective light as a process of searching for the roots of identity - the space of memory becomes a space of political struggle. It alludes to the capacity of preserving the past, but that capacity necessarily implies participation in the struggle for giving meaning and exercising power. ("Minefields" 29)

In the search for retrospective justice, even the partial justice of greater understanding, memory becomes a key, and contested, player.

The text demands the performance of humiliating and dehumanizing roles and an audience willing to countenance the spectacle. Una noche cualquiera presents a dilemma in that it requires the spectator's complicity with the stage violence in order to continue, yet aims to move that spectator, outside the theatre, to act. While no open "call to arms" is issued, the representation of the complicity - and worse - of the characters in the crimes described makes it clear that they are guilty. If the spectators maintain a passive stance as onlookers outside the theatre, they, too, will become guilty.

The stage directions describe a stage framed by the video cameras and surrounded by the audience, whose space is divided by four open passageways placed like the four compass points. The enclosure of the theatre-in-the-round is thus broken by the corridors, which are illuminated only where they meet the central stage and which provide both access to the stage and an intermediate area in which the actors can be partially off stage. The stage itself is minimally furnished, with four chairs "de diseño sofisticado" 
and a large, black table piled high with silver objects "acumulados en forma exagerada... que dan la ilusión de estar suspendidos en el espacio" (11). Visually, the stage is both crowded and empty, reflecting the paradoxical omnipresence of memory coupled with an equally pervasive public forgetting: the victimizers are everywhere, excessively visible and yet invisible, able to continue their lives without being called to account.

Marisa (a model), Marcelo (an actor), Pepe (a businessman and politician), and Luli (an upper-class woman) have gathered at Luli's home for an evening of drinks (though there is no alcohol in the house) and flirtation. Soon, Pepe storms out, accusing Luli of having her own designs on Marcelo and promising an unspecified revenge. The remaining three characters' uncomfortable, often aggressive, flirtation is interrupted by the appearance of Sandro and Musetti, who enter under pretext of making a delivery from the pub and then announce, flashing official-looking credentials, "Hubo una denuncia" (29). The two are dressed like the prototypical good cop/bad cop pairing of so many detective movies: Musetti of immaculate appearance with slicked-back hair, Sandro dressed more casually, in boots and jeans, his hair in a ponytail. Pepe later returns, revealing that he hired Sandro and Musetti to put a scare into the other three. However, Sandro and Musetti have plans of their own. They set in motion a series of increasingly violent and humiliating games. For instance, they oblige both Pepe and Marcelo to strip down to their underwear, and Pepe is compelled to prove his willingness to kill Marcelo at gunpoint; only after he repeatedly pulls the trigger is the weapon revealed to be unloaded. An obedient yet embarrassed Marcelo must get down on all fours while Sandro "trains" him like a dog. Luli, Marisa, and Marcelo are forced to make themselves up, clown style, until they resemble two prostitutes and a transvestite.

Many of these humiliations initially appear unmotivated. Gradually, it becomes clear that the purpose of all these exercises is to elicit confessions, and finally expressions of regret, from the four and to exact vengeance for their prior actions. Thus, under threat of arson, Luli admits that Pepe arranged the death of her husband (59). Other truths come out as well. Marcelo's willingness to betray the others in order to save himself is immediately apparent upon the thugs' arrival. In the course of the play, he is revealed as the informer responsible for the arrests of Sandro and Musetti's brother and sister-in-law (then five months pregnant). For her part, Marisa has always managed to ingratiate herself with those on the winning side. Her tendency 
toward such a strategy is evident throughout the play as she attempts to turn her seductive wiles on Musetti.

The official authority behind Sandro's and Musetti's actions is false. Their authority (or justification) rests, rather, on their status as aggrieved survivors. Their credentials and weapons are revealed as theatrical fakes (the badge is a membership card for an athletic club) and the physical violence is theatrical in the sense of being unreal, simulated but not achieved: no one is killed, the pistols do not fire. As props, the pistols also resemble the courtroom exhibit, for the pistol used to kill does not fire once it enters the courtroom as evidence. Nonetheless, the psychological violence is real. The play ends following Sandro's relation of the torture and deaths of his brother and sister-in-law. Pepe, Luli, Marcelo, and Marisa are obliged to kneel and Sandro sprinkles kerosene around them as they beg for mercy and forgiveness. Finally, Sandro and Musetti leave, taking nothing from the stage, leaving behind the one real pistol. At last the four cautiously raise their painted, tear-streaked faces. And the monitors "siguen vomitando imágenes como si nada" (106).

The play is yet to be performed. Although rehearsals were begun at the Teatro Municipal General San Martín in 2001, Torres Molina ultimately elected not to stage the play, opting instead to redevelop the piece as a screenplay. According to Torres Molina, after two weeks of rehearsals, she realized that the style was too "realistic," because of the thematic necessities of the play. With the premier date fast approaching, there was no time for the kind of study and rehearsal process that would have made possible a more challenging approach - in her words, "algo con una vuelta de tuerca, con cierto vuelo" (personal e-mail communication, 12/20/02). Yet the published text remains worth considering as a proposal, a confrontation of several media in the attempt to represent a cluster of perennially problematic concepts, among them justice, revenge, guilt, and memory. Also crucial is the element of chance, of arbitrary decisions or points of contact among individuals, memories, media.

In her study Wild Justice, Susan Jacoby writes: "Justice is a legitimate concept in the modern code of civilized behavior. Vengeance is not" (1). She argues that the "establishment of a balance between the restraint that enables people to live with one another and the ineradicable impulse to retaliate when harm is inflicted has always been one of the central tasks of civilization. The attainment of such a balance depends in large measure on the confidence of the victimized that someone else will act on their behalf against the victimizers. Laws are designed not to weed out the impulse toward 
revenge but to contain it in a manner consistent with the maintenance of an orderly and humane society" (5). Jacoby contends that there is a high price, both personal and social, to be paid for "the pretense that revenge and justice have nothing to do with each other" (12). Her point is that vengeance (retribution) is not necessarily bad nor is it intrinsically opposed to justice.

In Una noche cualquiera, the simultaneous processes of taping and staging make visible the invisible or overlooked. Torres Molina's play presents a context in which judicial remedy has been lacking, not, in this case, specifically as a result of lack of judicial will or an official decree of amnesty but because the crimes to be addressed, while real, are relatively invisible or undefined: Sandro and Musetti are going after the collaborators, the opportunists. A further implication of Torres Molina's play is that the judgment and trial of the prominently guilty (officers, torturers, junta members), partial and problematic as it might be, does not address the extent to which winners and losers, victims and victimizers, remain enmeshed at all levels of society, inevitably bumping against one another in the back and forth of daily life. Sandro and Musetti's rage grows, in part, out of the constant proximity and visibility of those responsible for the deaths they seek to avenge. Musetti explains that once he and Sandro decided to take justice into their own hands, finding their targets was easy: "Al revés, lo difícil era no verlos, porque aparecían en todos lados, los más campantes. Siempre en la vidriera. Supongo que confían en que la gente se olvida" (100). The play is a kind of trial, or more properly an act of interrogation, confession, and contrition. When Marisa insists that she had nothing to do with Luli's actions, and should therefore be allowed to leave, Musetti demurs: "Me encantaría poder complacerte, pero necesitamos testigos" (65). The audience, of course, also acts as witness, not only to what happens on stage but, via two of the monitors, to its own behavior. It is, in effect, seated in front of a mirror.

The ambivalence toward retribution that Jacoby describes might contribute to the undermining of audience sympathy or identification with any of the characters: neither victims nor vengeance-seekers are entirely sympathetic. The spectator would likely tend to sympathize initially with those whose sanctuary is being invaded. At the same time, not one of the "victims" is particularly likeable. As the motives behind Sandro and Musetti's actions are revealed, the two make a greater claim on audience sympathy. They have suffered great wrongs and their demand for an accounting is justified. Yet audience sympathy is made more problematic by the taboo against revenge 
and by the humiliations to which the others are subjected. Within the play, Sandro and Musetti's retribution is cruel and dehumanizing.

Tensions and uncertainties among the characters are evident at all levels; in no way do Luli and her guests present a united front against Sandro and Musetti. Thus, when Luli justifies her interruption of Marcelo and Marisa's mutual seduction with a request for another cigarette, Marcelo remarks sarcastically, "para alguien que nunca fuma, esto ya es un descontrol." Tellingly, Luli laughs nervously "al sentirse descubierta" (25). Her indirect seduction is a transparently awkward and ineffective performance. She will become more "uncovered" as the play continues.

More significant still is the link Marcelo offers between acting and memory. When Luli offers a half-hearted resistance to his embrace, he urges, "Relajate. ¿No conoces la técnica que usan los actores? Se llama memoria sensorial” (25). He continues, “¡Es muy interesante! Mirá, yo te acaricio y vos hacés memoria. Por ejemplo (le toca la rodilla) yo te acaricio acá... y vos tenés que ver a quién te hace acordar, ¿entendés?" (25). Luli, seduced, laughs uproariously. Marcelo's reference to the actor's use of "sense memory" parodies his misuse (or insincere employment) of acting technique as a sexual ploy and reminds the audience, however subtly, that all the memories here presented are being acted, reproduced. His comment reveals as well the interdependence of performance and memory. The need to stage the past, and a response to the past, draws on that interdependence. The phrase "hacer memoria" also underscores that recollection is an activity rather than a passive response.

Within the play, there are numerous references to Marcelo's television work (for instance, he is berated by Sandro and Musetti for being a secondrate actor of overblown material). Marcelo's greatest recent success has been as the hero of a telenovela. An actor on both stage and television, Marcelo echoes the commonplace privileging of theatre as more cultured or more elite, the superior art form. Of his current stage production, he notes that the audience is enthusiastic although the reviews are hostile. He alludes to an ignorant public impressed by an indecent theme and admits that many of the actors do not even know their lines, explaining, "pero casi todos estamos trabajando mucho en la tele" (14). Pepe gestures contemptuously toward one of the monitors as a way of explaining Marcelo's attractiveness to women, and Musetti explains condescendingly that the miraculous power of television "transforma a insectos, en galanes" (70). In one of the play's few instances of dramatic irony, Musetti urges Marcelo, "no seas tan llorón que no estás 
frente a las cámaras" (85). Yet the surrounding monitors are not otherwise mentioned, and the characters remain largely oblivious to the video apparatus. The audience, however, is confronted with a double layer of video images. The presence of the video monitors acts above all as a frame, directing and affecting audience interpretation.

The play presents an instance of vigilante justice being carried out in a quasi-courtroom setting. Sandro describes the "efecto boomerang" as infallible: what goes around, comes around (101). The remaining characters are pushed toward the recollection and admission of their individual guilt through a series of humiliations and attacks that range from the relatively mild embarrassment of being forced to strip to the very real threat of death at gunpoint. Thus, following a fake coin toss, Marcelo is condemned to die because, as Musetti informs him, the raft holds only five, and they are six. As a "courtesy," Pepe is chosen to fire the fatal shot. Marcelo and the others offer Sandro and Musetti anything they want - money, drugs, influence -if they will only spare his life, and a terrified Marcelo sobs piteously. When Pepe finally pulls the trigger, nothing happens. Musetti is disgusted to find the gun unloaded, for which he blames his own oversight. He tells Sandro, "Cargué el tuyo y me olvidé de cargar el mío," an admission that reduces the life-ordeath crisis just faced by Marcelo to an incident of careless housekeeping (77). Much later, when the true identities of Sandro and Musetti have been revealed and the four have admitted their several crimes, Marcelo's ordeal is further trivialized as Musetti mocks his victims: “¿Y estos revólveres?... son de utilería. Cualquiera se daría cuenta, pero a ustedes la cobardía les nubla el cerebro" (102). Only then does he remove a third pistol from the cartridge belt under his arm, saying, "Este sí es de verdad... claro que pueden dudar si quieren" (102).

Following another "game" of chance - a kind of eenie-meenie-mineymo using the words of the Argentine national anthem ${ }^{1}$ - Marcelo meekly submits to "obedience training" as if he were a dog; he is instructed to heel, and one of Luli's shoes is placed between his teeth. Sandro subsequently rummages through the women's purses in search of make-up, and Musetti directs the three: "En cinco minutos los quiero ver a los tres, coloridos y alegres como tres arco iris" (92). Marcelo, who had earlier been mocked for playing a gay man on stage, is transformed into a crude parody of a transvestite. Pepe, meanwhile, again at gunpoint, is obliged to reveal his role in arranging the death of Luli's husband and his subsequent profits both from that death and from his cooperation with the military, to whom he had offered 
the use of his warehouses when they ran short of space: "los detenidos... eran muchos... y no había donde ponerlos," Pepe explains; like merchandise, prisoners have to be put somewhere (95).

In seeking out their all-too-visible targets, Sandro and Musetti set out to counter the public amnesia or paralysis that the guilty might assume will protect them. In doing so, they draw upon notions of confession and contrition that depend on memory as a key component of evidence, a component that must be selected, channeled, and defined legally. As Philip Auslander argues, "memory is both policed by law and pressed into service as a mechanism for the enforcement of law" (113). Memory appears in the play through the past actions recalled and described by the individual characters and in the guise of documentation, the public memory (or legal evidence) that the tape of the performance could (implicitly) become. Although no future purpose for the tapes of the play is made explicit (they might easily be taped over or discarded), the presence and activity of the recording device signals the possible future use of the tapes as documentary evidence. This is particularly so in the context of a discussion (even, quite loosely, a prosecution) of crimes for which there is no direct evidence or documentation. Such crimes can easily disappear like the performance lost in the spectator's memory, the recollection never accessed.

In their discussion of the 1985 trial of the junta members who ruled Argentina from 1976 to 1983, Elizabeth Jelin and Susana G. Kaufman observe the ways in which proof and evidence were reconfigured in the juridical process. They write:

The construction of juridical proof was based on the testimony of the victims, since military records had mostly been destroyed.... Allowing testimony as proof followed the logic that what cannot be shown (the act of aggression) has to be told, but under precise and controlled conditions, so that what is denounced could be verified. In fact, what is acceptable as juridical proof is bodily injury. Feelings and sufferings cannot be measured and included. During testimony, they had to be suspended. When emotion overtook the witnesses, the judges halted testimony until calm and sanity returned. This intermittent pattern had a very special effect: the hidden message was that, in its full details, in its entirety, the experience could not be told; even less could it be heard. (94)

Testimony becomes proof, but only if it can be stripped of emotion. In a parallel situation, Jacoby describes the testimony of concentration camp 
survivors in the extradition hearings of Hermine Braunsteiner, a camp officer: "All of them were asked by Ryan's attorney whether they were 'out for revenge'; all replied in controlled, dispassionate tones that they only wanted justice. They were obviously aware... of the cultural convention that makes it unacceptable to acknowledge any form of vengeance as a motivation" (2). Where emotion overtakes the cool factuality of the juridical framework, where a desire for vengeance might intrude, it must be restrained. As Jelin and Kaufman further note, "Testimony in court is still the personal narrative of lived experience, but the juridical framework breaks it into components and pieces.... The discourse of the witness had to be detached from experience and transformed into evidence" (94).

In his discussion of the preference for live presence in U.S. legal procedure, Auslander notes that "to give testimony is to perform recollection, the retrieval of memory, in the present moment of the trial" (125). Auslander observes that "once they emerge from the safe haven of memory, recollections become visible and, therefore, subject to surveillance and to being pressed into service as testimony. It would seem that as soon as a memory is retrieved, it becomes available to the law" (154). The idea of memory being "pressed into service as testimony" contrasts with the notion of a voluntary assertion of the right to speak, a seeking out of a space in or from which to bear witness. "Testimony" itself may become both empowering and entrapping for the witness. Because it is simultaneously performed and filmed, the testimony presented in Una noche cualquiera is both live and not live. Auslander's phrase, "perform recollection," echoes the Spanish "hacer memoria"; what is "made" or performed here is both memory and documentation or evidence.

In addition to its role in the production of "evidence," the use of video in Una noche cualquiera might be seen as an instance of what Jay David Bolter and Richard Grusin term "remediation," which they define as "the representation of one medium in another" (339). Bolter and Grusin further note that "older media can also remediate newer ones" (345). Torres Molina's play presents a double remediation, of television through stage performance and of stage performance as quasi-broadcast. Although there is no mention in the script of video techniques such as the instant replay, the rebroadcast of the performance during the event presents a parallel with other "live" events that rely on mediatized images. As Auslander points out, "Live performance now often incorporates mediatization such that the live event itself is a product of media technologies" (24). This is the case with Una noche cualquiera, 
which combines live stage representation with the simultaneous recording and transmission of that representation as well as randomly selected broadcast television.

Bolter and Grusin also associate remediation with reform, noting that an "implicit and sometimes explicit goal of remediation is to refashion or rehabilitate other media" (346). Thus, "new technologies of representation proceed by reforming or remediating earlier ones, while earlier technologies are struggling to maintain their legitimacy by remediating newer ones" (352). Such technological or representational reform can also be viewed as a cause of social or political change. ${ }^{2}$ Torres Molina's inclusion of television and video within her play presents an instance of remediation in which the older medium takes in the newer one. The gesture may serve to legitimate the theatre by linking it more closely to the audience's customary experiences of representation. That the two (television and live performance) appear in largely parallel form, with little interconnection, places them on an even footing. The TV broadcast supplements the performance, offering the audience an alternative entertainment and admitting that the action on stage is not the only show in town. The audience's capacity to change the images also varies across media: the spectator's physical movement may be caught by the video camera, whereas the broadcast channels remain impervious to the actions or choices of either stage actors or theatre spectators. The structure of the play privileges the live action, yet the presence of the monitors and video cameras also reveals the live action as incomplete and draws attention to its distance from other media.

Auslander draws on what he refers to as Benjamin's "notion of a mass desire for proximity, and its alliance with a desire for reproduced objects" to discuss the intermingling of video with live performance (35). He observes that "Even in the most intimate of performance art projects, in which we may be only a few feet away from the performers, we are still frequently offered the opportunity for the even greater intimacy of watching the performers in close-up on video monitors, as if we can experience true proximity only in televisual terms" (35). ${ }^{3}$ The "better view" afforded by the televisual here applies to the spectator as much as to the performer, so that individual audience members may also become more visible, and "closer" to the other spectators. At the same time, the inclusion of the television broadcast also inserts a distancing effect, as the TV signals are drawn at random from the channels available at the time of the play's performance and are likely to bear little or no clear thematic relation to the images on the other screens - 
although it is certainly possible that the broadcasts may include programs more familiar, and so "closer," to the members of the audience than are the faces on the stage. Nor is there any guarantee of coherence; the shows on TV on a given night might be comic, might be game shows. Finally, the multiple monitors also multiply the viewer's choice, and that choice shapes what the audience sees: Is the individual spectator looking at the stage or at one of the monitors? Will she watch the simultaneous footage of the stage or of herself, or will she focus on one of the broadcast channels? While the inclusion of the monitors suggests an element of audience passivity or disengagement - the spectator can be watching TV even while at the theatre - the spectator has greater choice, and hence greater autonomy, as to where to direct her attention.

An element of chance plays an important role in the unfolding of Una noche cualquiera. Chance is present in the television broadcasts, which would necessarily vary with each performance, and in the arbitrary makeup of the audience, in which any given spectator might find herself in uncomfortable proximity to an adversary. Thus, the conflicts played out on stage might be uneasily echoed by the placement of one spectator beside another. While the play implicitly demands an extra-theatrical response from the spectators, it does so in a context in which the audience is given the opportunity, is perhaps even encouraged, simply to sit back and watch TV. The randomly selected images undermine the achievement of narrative closure, privileging an ability to watch whatever happens to be on (no matter how grim, how inane) without seeking a clear connection or meaning. The layered images offer as well a possible avenue of escape, should the stage images become overwhelming or intolerable. Finally, as with a news broadcast that includes a running strip of text at the bottom of the screen or that relies on a split-screen presentation, the layering of images also means that the audience is asked to watch and absorb ever more information simultaneously.

The flattening out that places all of the images on the same level (live, broadcast, simulcast) works in several directions. If the stage spectacle resembles, is in some ways the same as the TV broadcast, the TV broadcast is the "same" as the stage. For this reason, the audience may respond to the spectacle according to the conventions of both or of either one. The taping of the audience and the superimposition of multiple recorded images reflects the insidious spread of surveillance and repression throughout society, along with the culpability and complacency of ordinary citizens. The structure of Torres Molina's play also raises the question of how to maintain skepticism 
toward all representations and yet continue to use them. The monitors underscore the separation between audience and stage, belying the apparent immediacy of the representation and at the same time offering a kind of safety valve for the spectator potentially overwhelmed by the proximity of the broken characters of the final scene. ${ }^{4}$

Torres Molina uses the televisual in this play as a framing device, marking the borders of the stage much as the proscenium arch with its heavy drapes might. As frame, however, the presence of the video equipment and the images it transmits also shapes what happens on stage and how the audience perceives it. The combination of media demands that the audience attend to the means of representation. Torres Molina's play does not attempt to achieve transparency by erasing the evidence of the technologies of representation. Instead, the technology is placed before the audience, largely without comment, and the spectator is left to assimilate or interpret it as she sees fit. At the same time, if the audience is more accustomed to television than live theatre, the spectacle may achieve greater transparency or perhaps a greater degree of reality. Bolter and Grusin argue that "hypermedia and transparent media are opposite manifestations of the same desire: the desire to get past the limits of representation and to achieve the real. They are not striving for the real in a metaphysical sense. Instead, the real is defined in terms of the viewer's experience: it is that which evokes an immediate (and therefore authentic) emotional response" (343). Auslander suggests that "the ubiquity of reproductions of performances of all kinds in our culture has led to the depreciation of live presence, which can only be compensated for by making the perceptual experience of the live as much as possible like that of the mediatized" (36). ${ }^{5}$ It is possible that the images on stage seem "real" because they might have happened on television, although it is not clear if that is just what is happening in Una noche cualquiera. The filmed stage spectacle is implicitly similar to television "news" but also to a trial or to a movie. There is a tension, then, between the jumble of images that reproduce the spectator's visual experience of television and complicate (and perhaps make impossible) the construction of a coherent, rationalized narrative whole, and the notion of "real" or authentic. That is, the fragmentary may have become the authentic.

The question of "authenticity" is at issue throughout the play. The false props are displayed, the four characters figuratively on trial are derided as shams, their wealth condemned as ill-gotten. Yet to an audience accustomed to film violence, the images on the television screen may appear 
more real - their simulation less obvious, the medium more seemingly transparent - than what they see on stage. ${ }^{6}$ Perhaps in keeping with this element of audience expectation, the violence of the play is the more powerful because it consists of threats and humiliations, rather than actual blows. The degree of simulation, as compared with a staged fistfight or bleeding wound, is minimized, and the audience is not required to suspend its disbelief when the fight choreography is not convincing. The television broadcast further reproduces the ubiquity of the petty, and not so petty, criminals, reflecting their desire for visibility. Musetti declares: "Les gusta más que respirar, que se los vea" (80). That these encounters are unavoidable returns us, as well, to the price Jacoby notes for the attempt to achieve a separation between justice and vengeance, for the impulse toward retaliation must be continually reactivated in the victim or survivor in the course of such encounters. ${ }^{7}$

The crimes that most directly affect Sandro and Musetti, of course, are the torture and deaths of their brother and sister-in-law. In their description of the couple's suffering, many of the threads of the play come together, and the terms in which Marcelo was attacked are seen to reproduce the attacks on their relatives: anti-Semitism, homophobia, the actor as target. 8 When Marcelo identified the playwright (Panovich) in whose play he is appearing, Musetti asked, “¿Judío?" to which Marcelo replied "Sí, supongo que sí..." (32). Later, when Marcelo insists that he only plays a gay character, Sandro insists, "si elegiste hacer ese personaje, es porque te gusta," a suggestion Marcelo rejects by saying he needed the money (41). In the final moments of the play, once the four "perpetrators" are naked and kneeling, Sandro describes more thoroughly the suffering of his brother and sister-in-law: "Los torturaron y se ensañaron especialmente con ellos, porque Laura era judía. Y a Martín como era actor lo trataban de puto. Y después de tenerlos mucho peor que animales, peor que basura, después de humillarlos, de aterrorizarlos, durante meses... los mataron" (103). And there is no reason, no explanation, as he reminds his own victims: "Ustedes que preguntan todo el tiempo por qué... ¿ahora saben, por qué?" (103). Sandro's victims must now know why they have been targeted, but the deaths he and Musetti seek to avenge remain arbitrary, insufficiently explained - or inexplicable. There is no satisfying answer to the question he repeats, just at the limits of self-control: Why? Why?

No resolution is possible; no adequate justice or revenge. Sandro and Musetti more or less give up at the end, having achieved their aims (the confession and punishment of the guilty) but without having reached a fully 
cathartic or restorative resolution. That is, while Sandro and Musetti have punished their antagonists, through a mix of terror and humiliation, they have not achieved adequate or satisfying closure, a sense that balance or justice has been restored. Sandro wants an answer to his question, but beyond that, the two want true contrition: "Queremos escucharlos pedir perdón, pero pedir perdón de verdad. Queremos sentir que se arrepienten" (104). Jacoby points out that forgiveness is not a one-sided affair. She writes, "Both private and public forgiveness require two essential conditions: acknowledgment of responsibility on the part of the wrongdoer and a willingness to make amends based on genuine remorse" (347). Marcelo and the others are not invited to make restitution, but they must acknowledge their guilt. Sandro and Musetti want the real - not just their own authentic emotional response, but a sense that the emotion conveyed by Luli, Marcelo, Pepe and Marisa is authentic. Yet the spectacle here outlined suggests that such a degree of reality or authenticity is not available to us, certainly not on stage or screen. It is impossible to measure the authenticity of the performance - and Sandro and Musetti require "real," not performed emotion.

To invoke television in a play that attempts the representation of interpersonal violence is to echo what we all "know" to be true: television violence is ubiquitous, in fictional drama, "true" crime shows, news broadcasts, and music videos. The confrontation of the characters, in turn, reveals an equally inescapable, if often invisible, social violence present in the aftereffects of a period of violent repression. And while Sandro and Musetti have achieved a measure of retribution, at another level nothing has changed. The juxtaposition of the harsh exchanges on stage with a random selection of onair television programs both trivializes and valorizes the stage action by placing all of the images presented to the audience at a similar level. They are presented as all of a piece, suggesting that what the audience might watch on TV - might have been home watching even now, had they not opted to attend the play - is not substantially different. Because the audience is also the subject of recording and playback, it, too, becomes part of the undifferentiated array of images.

I want to return to that final note, the monitors "vomitando imágenes como si nada." The mix of images seems almost designed to jam the memory of the spectator, burying the stage action under a cascade of unrelated and incoherent or fragmentary images. This may be inherent to the theatre as much as to television. Jeanette Malkin argues: "One of the distinguishing features of postmodern memory-theatre is its overabundance of disconnected 
stimuli: conflicting discourses, intruding images, overlapping voices, hallucinatory fragments" (29). Remediation, here, does not achieve reform. Yet this may be the most appropriate way to approach the subject of violence and its consequences. As Malkin observes, in postmodern theatre, "Fragmentation and collage, for example, are not meant to shock the spectator into a reformed view of reality" (18). The images spat or thrown from the monitors are implicitly so much garbage, refuse, a torrent of uninterpreted and uncontrolled images without connection one to another, a mess from which the spectator might attempt to extract meaning but might just as easily choose to ignore, like a TV running in a bar, as mere insignificant background noise. And the justice - the retribution - sought by Sandro and Musetti is one more unresolved episode, one more show. The punishment is inevitably inadequate, the sense of closure not yet attained.

\section{University of Oregon}

\section{Notes}

Earlier versions of this essay were presented at the Latin American Theatre Today conference (Lawrence, Kansas, 2003), and at Penn State University in March, 2005. I thank Priscilla Meléndez for the invitation to Penn State, and members of the symposium for their comments and questions. I am also grateful to John Kronik, Analisa Taylor and Gina Herrmann, who read and commented upon earlier drafts.

1 "Oid-mor-tales-elgri-tosagra-doli-bertad-liber-tadli-bertad" (85).

2 Bolter and Grusin note, for example, claims that digital media such as the World Wide Web might serve to extend democratic participation.

3 A clear instance of this occurred in the performance by Guillermo Gómez-Peña and Emiko Lewis, "Mapa-Corpo: Oppositional Rites for a Borderless Society," presented at the Northwest Christian College Morse Events Center in Eugene, Oregon, January 25, 2005. During the performance, tiny US, British, and Israeli flags, mounted on acupuncture needles, were inserted at various points on the nude female performer's body. The placement of the needles was simultaneously filmed with a hand-held video camera, and the flags themselves were identifiable only on the video screen close-up. Without the video camera, the closeness of the stage may still not be close enough. The placement of the cameras in Torres Molina's play remains static: there is no provision for a camera operator who might zoom in on a given action. Rather, the cameras, as noted earlier, are mounted at the edge of the stage. The two facing the audience are described as "no fijas" so they might pan across the auditorium (11).

4 Auslander writes that, "reasserting the unbridgeable distinction between audience and performance, live performance foregrounds its own fractious nature and the unlikelihood of community" (57).

5 Auslander argues that "live performance thus has become the means by which mediatized representations are naturalized, according to a simple logic that appeals to our nostalgia for what we assumed was the im-mediate: if the mediatized image can be recreated in a live setting, it must have been 'real' to begin with" (38-39). 
6 This argument assumes, of course, that at least some of the images displayed by the broadcast channels will be violent. While by no means guaranteed, it seems highly likely.

7 An intriguing parallel to Sandro and Musetti's self-help justice is offered by the "escraches" Diana Taylor discusses in The Archive and the Repertoire. Taylor describes "escraches" as "acts of public shaming [that] constitute a form of guerrilla performance practiced by Argentina's children of the disappeared to target criminals associated with the Dirty War." Their protests "led participants directly to a perpetrator's home or office or to a clandestine torture center" (164).

8 See Diana Taylor's Disappearing Acts on the anti-Semitism of the dictatorship. Plays such as Gambaro's Información para extranjeros, among others, outline the repression of actors and others involved in the theatre. Jean Graham-Jones discuss both open and covert censorship and repression of theatre and theatre workers in Exorcising History.

\section{Works Cited}

Auslander, Philip. Liveness: Performance in a Mediatized Culture. New York: Routledge, 1999.

Bolter, Jay David, and Richard Grusin. "Remediation." Configurations 4.3 (1996): 311-58.

Dorfman, Ariel. Death and the Maiden. New York: Penguin, 1992.

Gambaro, Griselda. Atando cabos. Teatro. Vol. 6. Buenos Aires: Ediciones de la Flor, 1996: 7-26. [6 vols. 1984-96].

. Información para extranjeros. Teatro. Vol. 2. Buenos Aires: Ediciones de la Flor, 1987: 67-128. [6 vols. 1984-96].

Graham-Jones, Jean. Exorcising History: Argentine Theatre under Dictatorship. Lewisburg: Bucknell UP, 2000.

Jacoby, Susan. Wild Justice: The Evolution of Revenge. New York: Harper and Row, 1983.

Jelin, Elizabeth. "The Minefields of Memory." NACLA Report on the Americas 32.2 (1998): 23-29.

Jelin, Elizabeth, and Susana G. Kaufman. "Layers of Memories: Twenty Years after in Argentina." The Politics of War Memory and Commemoration. Ed. T.G. Ashplant, Graham Dawson and Michael Roper. London: Routledge, 2000: 89-110.

Malkin, Jeanette R. Memory-Theatre and Postmodern Drama. Ann Arbor: U of Michigan P, 1999.

Taylor, Diana. The Archive and the Repertoire: Performing Cultural Memory in the Americas. Durham: Duke UP, 2003.

. Disappearing Acts: Spectacles of Gender and Nationalism in Argentina's "Dirty War." Durham: Duke UP, 1997.

Torres Molina, Susana. Una noche cualquiera. Sevilla: Área de Cultura, Ayuntamiento de Sevilla, 1999. 